\title{
Screening of Urdbean (Vigna mungo (L) Hepper) Genotypes against ULCV in Relation to Epidemiological Factors
}

\author{
Khaleeq-ur-Rehman ${ }^{1}$, Yasir Iftikhar ${ }^{1}$, Yasir Ali ${ }^{2, *}$, Owais Yasin², Usman Arshad ${ }^{2}$, \\ Waqas Ahmed Khan ${ }^{2}$, Arslan Hafeez ${ }^{3}$, Muhammad Jafir ${ }^{4}$, Shafqat Ali ${ }^{2}$ \\ ${ }^{1}$ Department of Plant Pathology, University College of Agriculture, University of Sargodha, Sargodha, Pakistan \\ ${ }^{2}$ Department of Plant Pathology, University of Agriculture Faisalabad, Pakistan \\ ${ }^{3}$ Department of Botany, University of Agriculture Faisalabad, Pakistan \\ ${ }^{4}$ Department of Entomology, University of Agriculture Faisalabad, Pakistan
}

Copyright $\bigcirc 2018$ by authors, all rights reserved. Authors agree that this article remains permanently open access under the terms of the Creative Commons Attribution License 4.0 International License

\begin{abstract}
Urdbean or mashbean is one of the most valuable leguminous crops all over the world. It is under the attack of numerous diseases caused by different pathogens. Among these urdbean leaf crinkle virus (ULCV) is one of the most devastating and widely distributed. It is naturally transmitted through whitefly (Bemisia tabaci). To combat this problem, eight urdbean genotypes (Arooj, 6065-3, 6036-21, 4em-716, ES-I, M-95, ARRIM-08 and ARRIM-16) were screened out against urdbean leaf crinkle virus and correlated with epidemiological factors (temperature, relative humidity). The overall results revealed that, among all these lines, one genotype (M-95) was susceptible, three genotypes (6065-3, 4em-716, ES-I) were moderately susceptible, three genotypes (6036-21, ARRIM-08, ARRIM-16) moderately resistant and only one genotype showed resistance response to urdbean crinkle virus. A positive correlation was observed between disease prevalence and all environmental factors.
\end{abstract}

Keywords Disease prevalence, Genotypes, Relative Humidity, Urdbean Leaf Crinkle Virus, Vigna mungo

\section{Introduction}

The pulses are rich source of protein; due to this they are also called "poor man's meat". The protein content of various pulses ranges from 17-24 percent which is about 2-3 times more than cereals. Mashbean contain 25-26 percent protein and 61 percent carbohydrates while mungbean include 20.8-33.1 percent protein and 62-64 percent carbohydrates [5]. Pulses are also termed as short duration crops. All pulses require a small quantity of water, therefore they are also known as dry crops [6]. Urdbean
(Vigna mungo (L) Hepper, F. Leguminosae) is also called black gram. It is local to India and grown in practically all the continents i.e. Europe, Australia, Asian, Africa and America. However conventional development of this pulse crop is basically kept in the nations of south Asia and contiguous area including Pakistan, Sri Lanka, Bangladesh, Afghanistan and India. In Pakistan it covers an area of 20.9 thousands hectares with annual production of 10.2 thousand tons grains and its yearly production decreased by $6.4 \%$ (Anonymous, 2014). On the other hand, in combination with grain Urdbean seed satisfies the prerequisite of protein $(24 \%)$ in diets, less amount of sulphur containing amino acids, lycine and phosphoric acid [13]. It is mostly utilized as "dal" and in preparation of some extraordinary dishes like the sprouted urdbean which is extremely prominent dish in Japan and is exceedingly regarded for digestibility [16]. Due to the leguminous plant, it could be nodulated by rhizobia, bringing about the development of another organ (i.e., nodule) and securing a nitrogen-altering symbiosis [15]. The low yield of harvest is due to a few biotic and a biotic components (Anonymous, 2001). Biotic stresses, for example infection encourage serious economic losses to numerous yields all over the world [11]. Urdbean leaf crinkle virus (ULCV) cause losses underway and in this manner destroys the yield depending upon season and verities developed [17]. Plant diseases should be controlled by using resistance germplasm which were considered as strong and economic method mostly due to viruses. Under the various environmental conditions the screening of blackgram verities against ULCV, to recognize the resistance resources has been described by [7]. Keeping in view above mention facts the present study was conducted (1) to screen urdbean genotypes against ULCV disease under natural environmental conditions and (2) to observe the 
impact of environmental factors on disease development.

\section{Materials and Methods}

Eight (08) lines of urdbean (Vigna mungo) were collected from the Institute of Pulses, Ayub Agriculture Research Institute, Faisalabad. The research was conducted during summer season 2014 in Department of Plant Pathology, University College of Agriculture, University of Sarghodha. The screening of urdbean (Vigna mungo) germplasm was done against urdbean leaf crinkle virus (ULCV) under field conditions

Each test variety was planted in single non replicated rows with 1 feet length and $30 \mathrm{~cm}$ planting distance. After the 7 days of plantation, thinning was frequently performed to maintain the 30 plants per row (15cm apart). An irrigation practice was done at 2-3 weeks intervals to prevent the crop from drought conditions. Weeding was done to maintain the field free from weeds and to make easy observations.

\section{Data Recording}

After two weeks of planting, the first appearance of urdbean crinkle virus (ULCV) was recorded on 26th September 2014 in various varieties. Mild to severe attack was first recorded on young leaves and then curling and rugosity of leaves appeared. Infected plants were counted and percent disease progression recorded on each occasion. Data for disease severity was recorded following $0-5$ rating scale as described by Bashir et al. [5] (Table 1) and disease incidence was recorded using following method [6].

$$
\text { Disease incidance }=\frac{\text { No.of infected plant }}{\text { Total number of plant }} \times 100
$$

Table 1. Disease rating scale (0-5) used to record the severity index

\begin{tabular}{|c|c|c|}
\hline Severity & \% Infection & Infection category \\
\hline 0 & $\begin{array}{c}\text { All plants free of virus } \\
\text { symptoms }\end{array}$ & HR \\
\hline 1 & $1-10 \%$ infection & R \\
\hline 2 & $11-20 \%$ infection & MR \\
\hline 3 & $21-30 \%$ infection & MS \\
\hline 4 & $30-50 \%$ infection & S \\
\hline 5 & More than $50 \%$ & HS \\
\hline
\end{tabular}

\section{Relationship of Environmental Factors with ULCV}

The environmental data on various factors i.e. minimum and maximum temperature, relative humidity and rain fall throughout the crop growth period was collected from the Department of Citrus research Institute (CRI) Sargodha.

\section{Statistical Analysis}

The data was subjected to ANOVA at 5\% level of significance. The environmental and disease prevalence data were subjected to correlation and regression analysis to determine the relationship of environment with the disease development [19].

\section{Results}

\section{Screening of Urdbean Genotypes under Field Conditions}

During first week five genotypes (6065-3, 6036-21, 4eM-716, ES-I and ARRIM-18) showed resistant response and only one genotype (M-95) exhibited susceptible response with $20 \%$ disease infection. The disease progressed and spread in the second week, only one genotype (M-95) expressed maximum infection (30\%) and one genotypes (4eM-716) showed moderately resistance reaction. The rest one was remained asymptomatic. In third week observation, maximum disease infection was recorded in genotype (M-95) showed susceptible reaction $(40 \%)$ while three genotypes (6065-3, 4eM-716 and ES-I) found to be moderately resistant. While during fourth week observation two genotype (M-95) and (6065-3) were found to be susceptible and moderately susceptible with disease severity 30 and $40 \%$ respectively. The disease progressed very fast in the fifth week as out of 8 genotypes one genotype (M-95) was found to be highly susceptible with $50 \%$ disease infection and three genotypes (6065-3, 4eM-716 and ES-I) showed moderately susceptible reaction. In 6th and 7th observation, one test line/genotype (M-95) was observed highly susceptible, three genotypes (6065-3, 4eM-716 and ES-I) susceptible, three test lines (6036-21, ARRIM-08 and ARRIM-16) were found to be moderately susceptible and only one genotype (Arooj) was above the border of resistance (Table 2 and Figure 1).

\section{Disease Incidence}

Analysis of variance (ANOVA) represented that highly significant results were found to exist among various genotypes of urdbean (Table 3). Comparison of means revealed that M-95 (44) had maximum disease incidence which differed significantly from all other genotypes. Genotypes 4em-716, 6065-3, 036-21, ARRIM-16 and ARRIM-08 showed non-significant differences having disease incidence $24,6,10,10$ and $7 \%$ respectively. Minimum disease incidence was observed on Arooj (4) which is also significantly different from all other genotypes (Figure 2). 
Table 2. Overall progress of ULCV infection in different urdbean genotypes

\begin{tabular}{|c|c|c|c|c|c|c|c|c|c|}
\hline Sr. No. & Varieties & $26-09-14$ & $02-10-14$ & $13-10-14$ & $21-10-14$ & $30-10-14$ & $10-11-14$ & $20-11-14$ & Reaction \\
\hline 1 & Arooj & 0 & 0 & 1 & 1 & 1 & 1 & 1 & R \\
\hline 2 & $6065-3$ & 1 & 1 & 2 & 3 & 3 & 4 & 4 & MS \\
\hline 3 & $6036-21$ & 1 & 1 & 1 & 1 & 2 & 2 & 2 & MR \\
\hline 4 & 4 em-716 & 1 & 2 & 2 & 2 & 3 & 4 & 4 & MS \\
\hline 5 & ES-I & 1 & 1 & 2 & 2 & 3 & 4 & 4 & MS \\
\hline 6 & M-95 & 2 & 3 & 4 & 4 & 5 & 5 & 5 & S \\
\hline 7 & ARRIM-08 & 0 & 0 & 1 & 1 & 2 & 2 & 2 & MR \\
\hline 8 & ARRIM-16 & 1 & 1 & 1 & 1 & 1 & 2 & 2 & MR \\
\hline
\end{tabular}

$\mathrm{S}=$ Susceptible, $\mathrm{MS}=$ Moderately susceptible, $\mathrm{MR}=$ Moderately resistant, $\mathrm{R}=$ Resistant, $\mathrm{HR}=$ Highly resistant

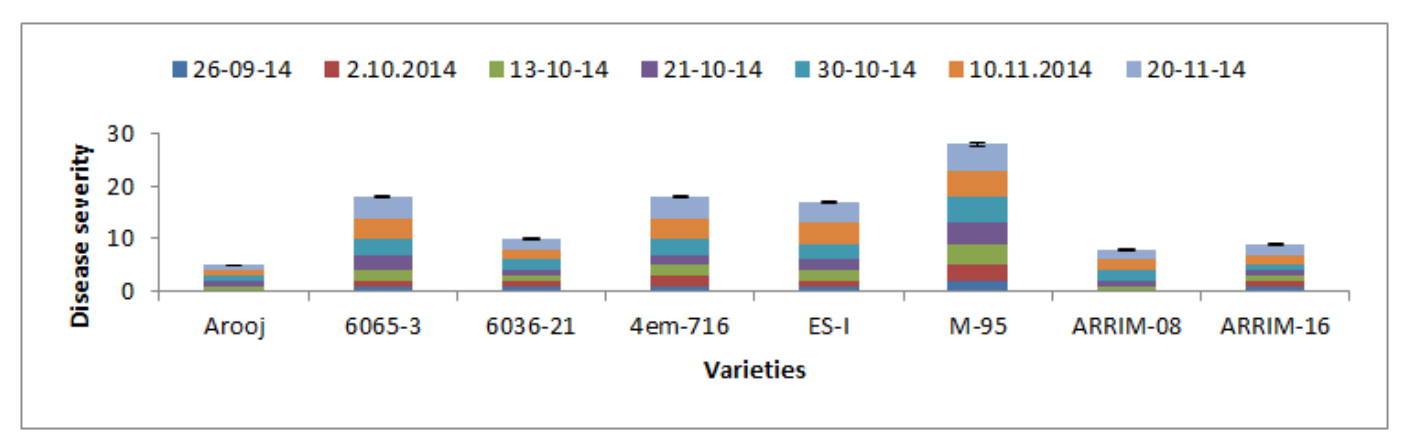

Figure 1. Overall progress of ULCV infection in different urdbean genotypes

Table 3. Analysis of variance and comparison of means of the data recording the disease severity of different cultivars of urdbean

\begin{tabular}{|c|c|c|c|c|c|}
\hline S.O.V. & D.F. & S.S. & M.S. & F. value & P value \\
\hline Varieties & 7 & 56.411 & 8.05867 & $8.68 * *$ & 0.0000 \\
\hline Error & 48 & 44.571 & 0.92857 & & \\
\hline Total & 55 & 100.982 & & & \\
\hline
\end{tabular}

Grand Mean 2.0179; CV 47.75

** = Highly significant at $5 \%$ probability level

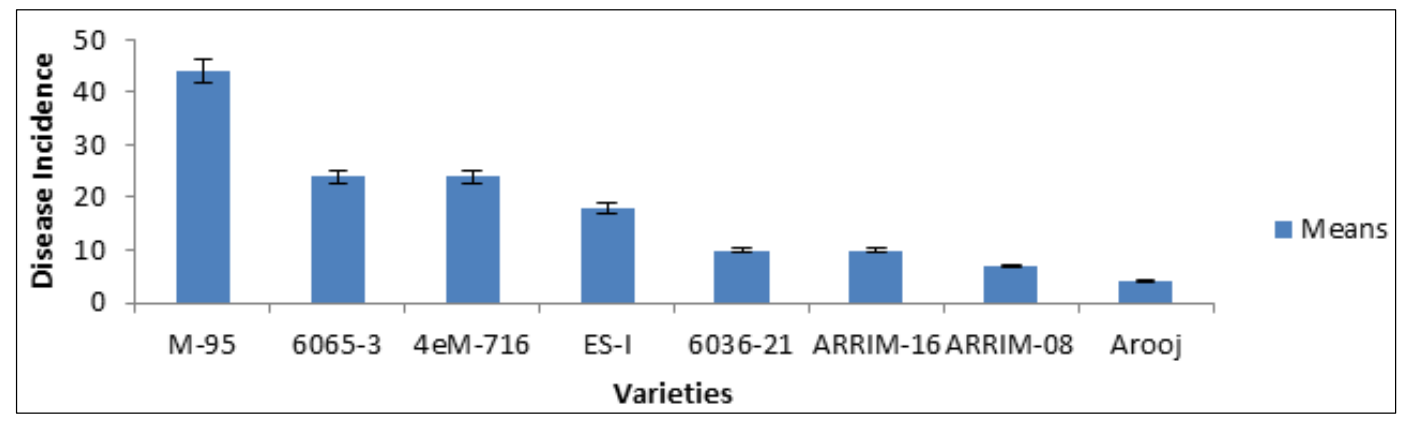

Figure 2. Comparison of means for the disease incidence of different urdbean cultivars

Table 4. Analysis of variance and comparison of means of the data recording the disease severity of different cultivars of urdbean

\begin{tabular}{|c|c|c|c|c|c|}
\hline S.O.V. & D.F. & S.S. & M.S. & F. value & P value \\
\hline Varieties & 7 & 56.411 & 8.05867 & $8.68^{* *}$ & 0.0000 \\
\hline Error & 48 & 44.571 & 0.92857 & & \\
\hline Total & 55 & 100.982 & & & \\
\hline
\end{tabular}

Grand Mean 2.0179; CV 47.75

$* *=$ Highly significant at $5 \%$ probability level. 


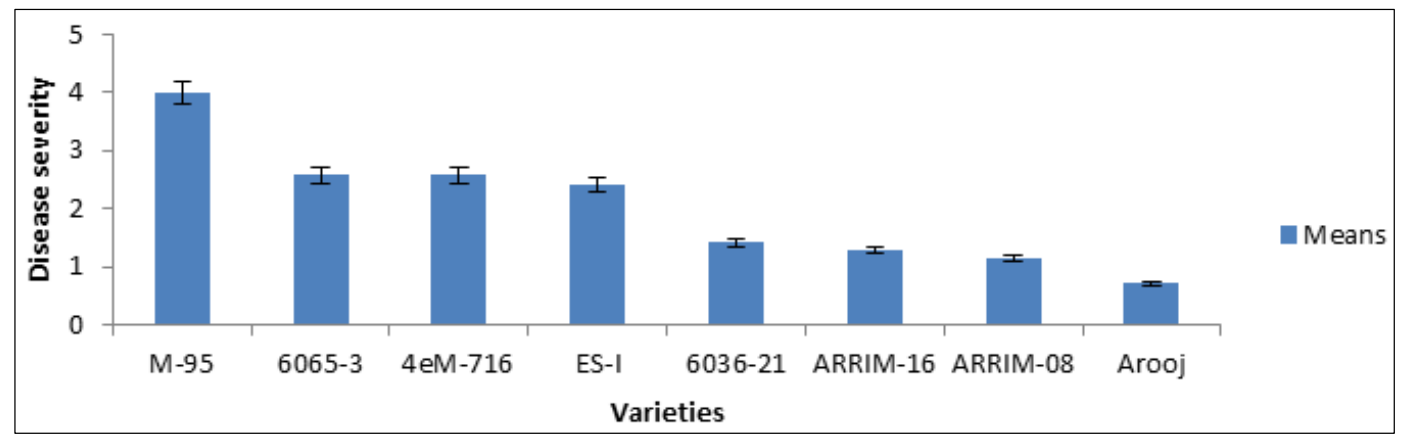

Figure 3. Comparison of means of disease severity of different urdbean cultivars

\section{Disease Severity}

Disease severity \%age influence the activity of plants and it was clear from data pertaining to disease severity that significant differences existed between various genotypes of urdbean genotypes (Table 4). The genotype M-95 showed maximum disease severity (4) which showed clear difference from other genotypes. Genotypes 4eM-716 (2.57), 6065 (2.57), ARRIM-16 (1.28), ARRIM-08 (1.14) and Arooj (0.71) showed non-significant differences to each other (Figure 3).

\section{Relationships between Environmental Factors and ULCV Infection}

Table: 2. Correlation between disease severity and Environmental factors

\begin{tabular}{|c|c|c|c|}
\hline Cultivars & Max. temp. $\left({ }^{\circ} \mathrm{C}\right)$ & Min. temp. $\left({ }^{\circ} \mathrm{C}\right)$ & RH $(\%)$ \\
\hline \multirow{2}{*}{ Arooj } & $-0.932^{*}$ & $-0.967^{* *}$ & -0.243 \\
& 0.021 & 0.002 & 0.736 \\
\hline \multirow{2}{*}{$6065-3$} & $-0.936^{*}$ & $-0.965^{* *}$ & -0.120 \\
& 0.018 & 0.003 & 0.772 \\
\hline \multirow{2}{*}{$6036-21$} & $-0.941^{*}$ & $-0.985^{* *}$ & 0.868 \\
& 0.021 & 0.002 & 0.740 \\
\hline \multirow{2}{*}{4 eM-716 } & $-0.923^{*}$ & $-0.992^{* *}$ & -0.252 \\
& 0.026 & 0.003 & 0.755 \\
\hline \multirow{2}{*}{ ES-I } & $-0.932^{*}$ & $-0.988^{* *}$ & -0.321 \\
& 0.024 & 0.002 & 0.628 \\
\hline \multirow{2}{*}{ M-95 } & -0.827 & $-0.936^{*}$ & -0.313 \\
& 0.071 & 0.027 & 0.623 \\
\hline \multirow{2}{*}{ ARRIM-08 } & $-0.965^{* *}$ & $-0.977^{* *}$ & -0.158 \\
& 0.011 & 0.002 & 0.781 \\
\hline \multirow{2}{*}{ ARRIM-16 } & $-0.939^{*}$ & $-0.998^{* *}$ & -0.068 \\
& 0.022 & 0.002 & 0.928 \\
\hline
\end{tabular}

Upper values indicated Pearson's correlation coefficient; Lower values indicated level of significance at $5 \%$ probability; * = Significant $(\mathrm{P}<0.05)$; $* *$ = Highly significant $(\mathrm{P}<0.01)$

Environmental factor i.e. maximum and minimum temperature and relative humidity had influenced the disease severity and disease incidence. The results of correlation revealed that maximum temperature had significant correlation with disease severity on all urdbean genotypes except M-95 which showed non-significant correlation. Five urdbean genotypes exhibited negative non-significant correlation with disease incidence and maximum temperature. Maximum temperature did not favored the disease severity in M-95 and also for disease incidence in five urdbean genotypes 4eM-716, ES-I, M-95, ARRIM-08 and ARRIM-16. Minimum temperature showed significant negative correlation with disease severity. Minimum temperature favored the disease severity in all three urdbean genotypes but on five genotypes 4eM.716, ES-I, M-95, ARRIM-08 and ARRIM-16 minimum temperature had no impact of disease incidence. While relative humidity had non-significant impact on both disease severity and disease incidence (Table 5 and 6 ).

Table 3. Correlation between disease incidence and Environmental factors

\begin{tabular}{|c|c|c|c|}
\hline Cultivars & Max. temp. $\left({ }^{\circ} \mathrm{C}\right)$ & Min. temp. $\left({ }^{\circ} \mathrm{C}\right)$ & RH $(\%)$ \\
\hline \multirow{2}{*}{ Arooj } & $-0.975^{* *}$ & $-0.936^{*}$ & -0.124 \\
& 0.006 & 0.027 & 0.863 \\
\hline \multirow{2}{*}{$6065-3$} & $-0.927^{*}$ & $-0.935^{*}$ & -0.312 \\
& 0.025 & 0.016 & 0.612 \\
\hline \multirow{2}{*}{$6036-21$} & $-0.927^{*}$ & $-0.985^{*}$ & -0.341 \\
& 0.021 & 0.015 & 0.613 \\
\hline \multirow{2}{*}{$4 \mathrm{eM}-716$} & -0.786 & -0.848 & -0.538 \\
& 0.124 & 0.064 & 0.348 \\
\hline \multirow{2}{*}{ ES-I } & -0.742 & -0.858 & -0.558 \\
& 0.124 & 0.068 & 0.332 \\
\hline \multirow{2}{*}{ M-95 } & -0.864 & -0.797 & -0.175 \\
& 0.072 & 0.138 & 0.767 \\
\hline \multirow{2}{*}{ ARRIM-08 } & -0.834 & -0.758 & -0.187 \\
& 0.073 & 0.128 & 0.766 \\
\hline \multirow{2}{*}{ ARRIM-16 } & -0.854 & -0.755 & -0.185 \\
& 0.076 & 0.133 & 0.786 \\
\hline
\end{tabular}

Upper values indicated Pearson's correlation coefficient; Lower values indicated level of significance at $5 \%$ probability; $*$ = Significant $(\mathrm{P}<0.05)$; $* *$ Highly significant $(\mathrm{P}<0.01)$

\section{Characterization of Environmental Factors Conducive for Urdbean Leaf Crinkles Virus Disease Development}

Four genotypes i.e. 6065-3, 4eM-716, ES-I and M-95 were selected and subjected to regression analysis to characterize the critical ranges of environmental conditions (maximum and minimum temperature and relative humidity) conducive for urdbean leaf crinkles virus disease development. Results demonstrated that all genotypes showed highest disease severity when maximum temperature was decreased from 30 to $24.65{ }^{\circ} \mathrm{C}$. The relationship was best explained by linear regression models 
as indicated by $0.93,0.89,0.94$ and $0.83 \mathrm{r}$ values (Figure 4 ). The regression between minimum temperature and \% ULCV infection was found negative on all selected urdbean genotypes. The ULCV disease severity decreased when minimum temperature increased 8.5 to $17.5^{\circ} \mathrm{C}$. The relationship was best explained by linear regression models as indicated by $0.94,0.84,0.94$ and $0.85 \mathrm{r}$ values (Figure 5).
There was positive correlation between relative humidity and infection of ULCV in four urdbean genotypes. All the genotypes showed non-significant correlation. It was found that there was no impact of relative humidity in ULCV infection. The relationship was best explained by linear regression models as indicated by $0.51,0.17,0.35$ and 0.23 $r$ values (Figure 6).

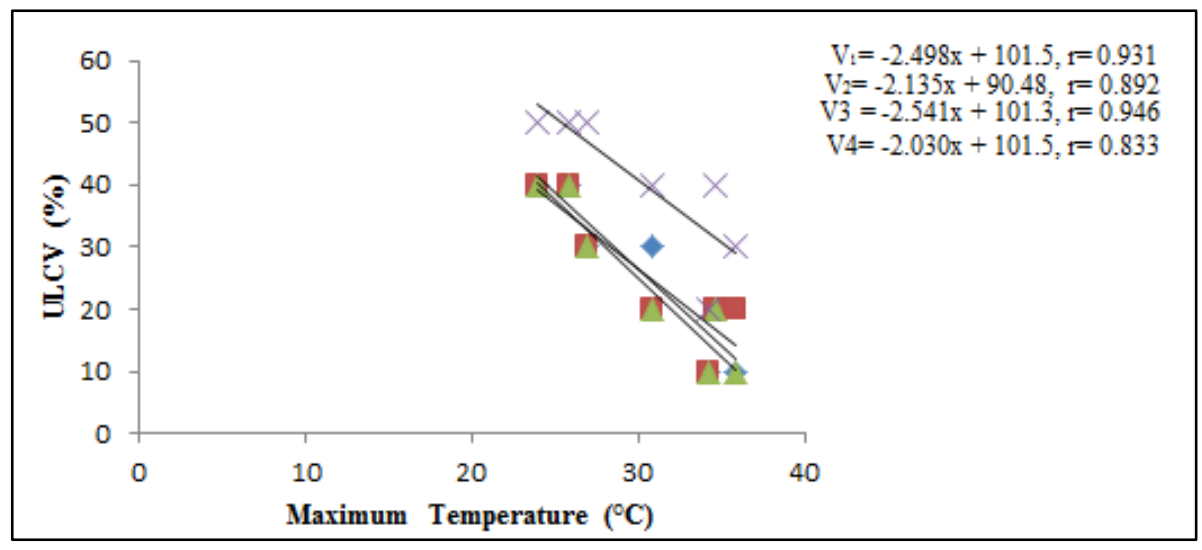

Figure 4. Relationship of maximum temperature with ULCV disease severity recorded on five urdbean genotypes (6065-3, 4eM-716, ES-I and M-95)

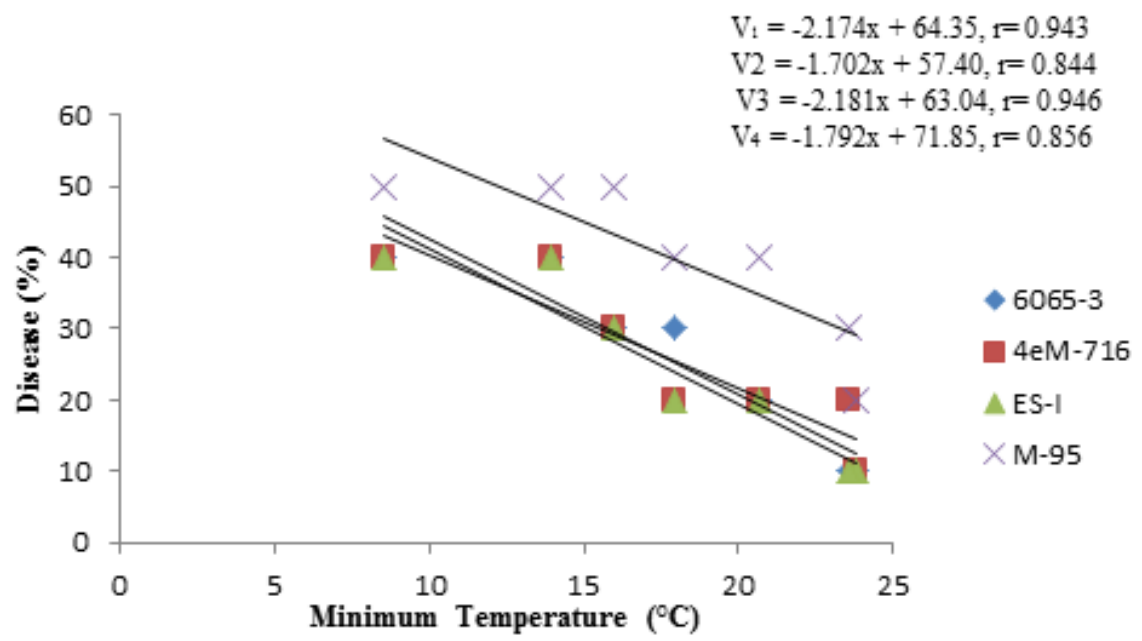

Figure 5. Relationship of minimum temperature with ULCV disease severity recorded on five urdbean genotypes (6065-3, 4eM-716, ES-I and M-95)

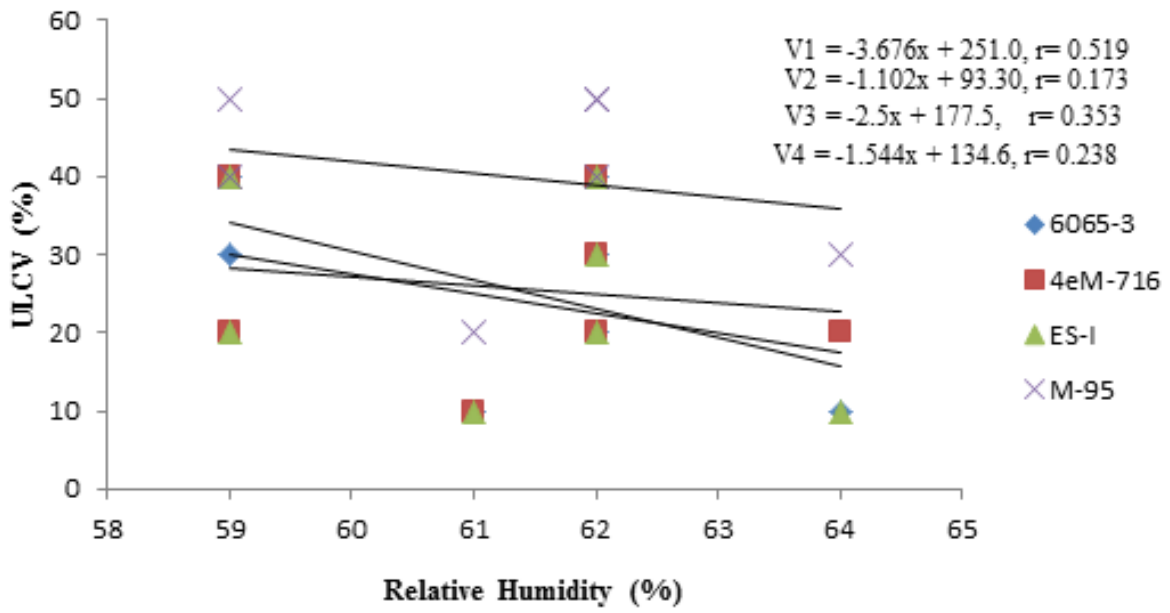

Figure 6. Relationship of relative humidity with ULCV disease severity recorded on five urdbean genotypes (6065-3, 4eM-716, ES-I and M-95) 


\section{Discussion}

Urdbean leaf crinkle virus (ULCV) is an important, common and most destructive disease in Pakistan and other countries growing food legumes in summer. High disease incidence is determined every year, which are attributed to the combination of different factors such as occurrence of inoculums potential, suitable ecological / environmental conditions and high white fly population. Assessment of disease resistance genotypes are considered as durable and an efficient solution of minimizing urdbean crinkle virus (ULCV). Therefore, screening of urdbean genotypes against ULCV under natural conditions was performed [7, $8,12,18]$.

Among environmental factors temperature played an important role in disease development. The results concluded that five urdbean genotypes had showed non-significant correlation with disease incidence and maximum temperature. Maximum and minimum temperature had negative impact on all urdbean genotypes. Our results are similar with the results of Ashfaq [4]. At low temperature disease incidence did not increased in all urdbean genotypes. These results are disagreement with Kadian [14] who found that above $70 \%$ relative humidity favored the disease development.

\section{REFERENCES}

[1] M. Ashfaq, M.A. Khan, N. Javed, S.M. Mughal, T. Mukhtar and M. Bashir. Evaluation of Urdbean germplasm for resistance against leaf crinkle virus. Pakistan Journal of Botany. 39(6):2103-2111, 2007.

[2] Anonymous 2001. Agriculture statistics of Pakistan. Ministry of Food, Agriculture and livestock. Govt. of Pakistan. Food and Agri. Division. Planning Unite Islamabad. $\mathrm{p}: 13$.

[3] Anonymous. 2014. Agricultural Statistics of Pakistan. Ministry of Food, Agricultural and Livestock. Govt. of Pakistan. Food and Agric. Division. Planning Unit Islamabad.

[4] M. Ashfaq, M.A. Khan, N. Javed. Characterization of environmental factors conducive for urdbean leaf crinkle (ULCV) disease development. Pakistan Journal of Botany. 40(6):2645-2653, 2008.

[5] M. Ashfaq, M.A. Khan, T. Mukhtar and S.T. Sahi. Role of mineral metabolism and some physiological factors in resistance against urdbean leaf crinkle virus in blackgram genotypes. International Journal of Agriculture and Biology. 16: 189-194, 2014.

[6] M. Ashfaq, M. A. Khan, S.M. Mughal, N. Javed, T. Mukhtar and M. Bashir. Evaluation of Urdbean germplasm for resistance against Urdbean leaf crinkle virus. Pakistan Journal of Botany. 39(6): 2103-2111, 2007.

[7] M. Bashir. Studies on viral diseases of major pulse crops and identification of resistance source. Technical Annual Report (April, 2003 to March, 2004) of ALP Project. Crop Science Institute, NARC, Islamabad. P. 149, 2004.

[8] M. Bashir, B.A. Mailk. Disease of major pulse crops in Pakistan: A review. Tropical Pest Management. 34: 309-314, 1988.

[9] M. Bashir, M.Z. Ahmad and S. Mansoor. Occurrence and distribution of viral diseases of mungbean and mashbean in Punjab. Pakistan. Pakistan Journal of Botany. 38(4): 1341-1351, 2006.

[10] M. Bashir, M. Zubair. Identification of resistance in urdbean (Vigna mungo) against two different viral diseases. Pakistan. Pakistan Journal of Botany. 34:49-51, 2002.

[11] S.P. Beniwal, S.J. Kolte and Y.L. Nene. Nature and rate of spread of urdbean leaf crinkle disease under field condition. Indian Journal of Mycology \& Plant pathology. 98(2):88-92, 1983.

[12] J.S. Brar, H.S. Rataul. Some field characteristics of leaf crinkle virus of urdbean, Vigna mungo (L) Happer, Indian Journal of Virology. 2:49-56, 1986.

[13] C.M. Duffus, and J.C. Slaughter. Seeds and their use. Wiley and sons Chichester, New York, USA. p: 60-64, 1980.

[14] O.P. Kadian. 1982. Yield loss in mungbean and urdbean due to leaf crinkle disease. Indian Journal of Phytopathology. 35: 642-644.

[15] J. Loh, G. Stacey. Nodulation gene in bradyrhizobium japonicum: a unique integration of global regulatory circuits. Applied \& Environmental Microbiology. 69:10-17, 2003.

[16] K.O. Rachie and L.M. Roberts. Grain legumes of the lowland tropics. Advances in Agronomy. 26:1-132, 1974.

[17] Reddy, C.H. Ravandar, A. Vilas, S. Tonapi, S.S. Varanavasiappn, S. S. Navi, and R. jayarajan. Management of urdbean leaf crinkle virus in urdbean (Vigna mungo L. Hepper). International Journal of Agricultural Sciences. $1(2): 8-10,2006$

[18] F.J. William, J.S. Grewal, K. S. Amin. Serious and new diseases of pulse crops in India in 1966 Plant Disease. 52: 300-304, 1968.

[19] R.G. Steel, J.H. Torrie, and D.A. Deekey. Principles and procedures of statistics. A biometrical approach. $3^{\text {rd }} \mathrm{Ed}$. McGraw Hill Book Co. Inc. N. Y. USA, 1997. 